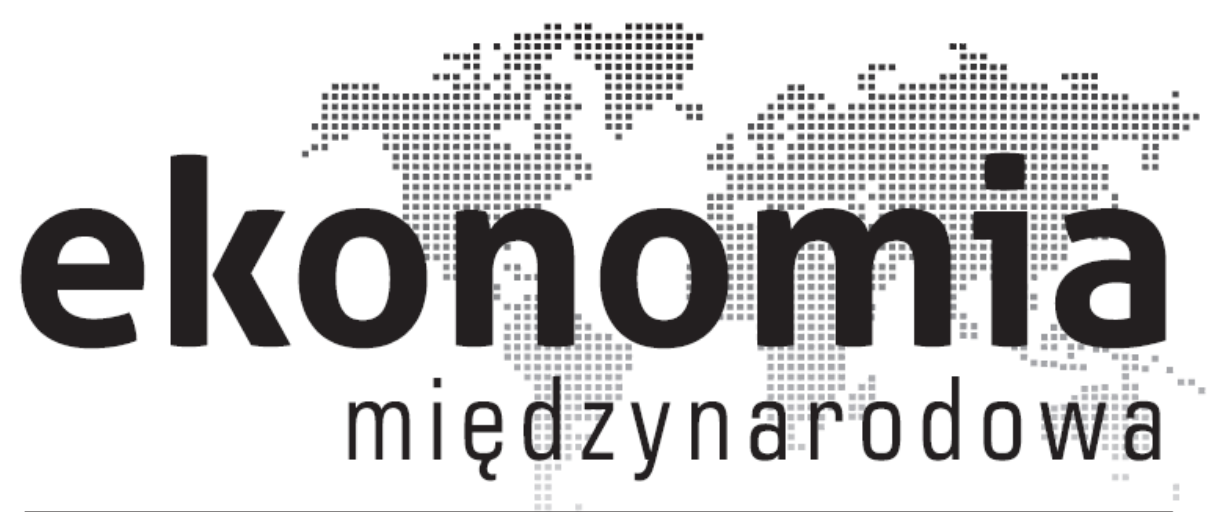

Ekonomia Międzynarodowa

Nr 14 (2016)

Wydawca: Uniwersytet Łódzki

(Publisher: University of Lodz)

www.ekonomia-m.pl

ISSN: 2082-4440 - wydanie papierowe (paper edition)

ISSN: 2300-6005 - wydanie elektroniczne (electronic edition)

Wersja elektroniczna czasopisma jest wersją referencyjną

(Electronic edition is the reference version of the journal)
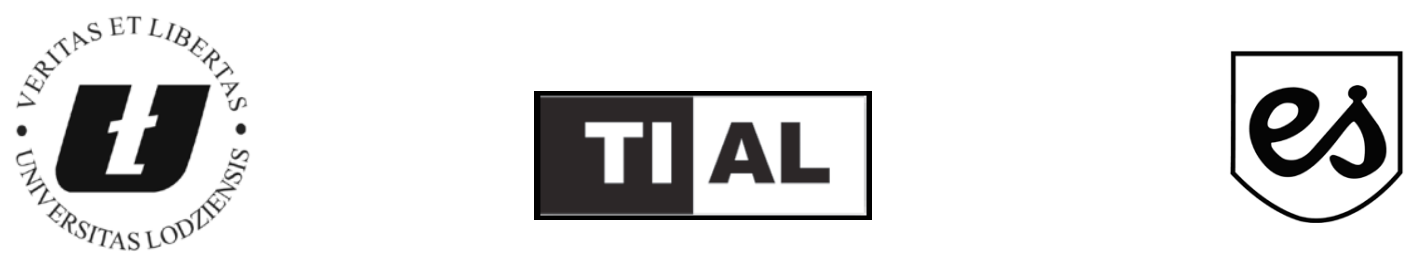


\section{Metody pomiaru e-administracji w kontekście konkurencyjności międzynarodowej}

Natalia Mańkowska*

\section{Wstęp}

Od dwóch dekad w krajach Unii Europejskiej kładzie się szczególny nacisk na tworzenie infrastruktury oraz zwiększanie stopnia wykorzystywania technologii informacyjnych i komunikacyjnych (ang. Information and Communication Technologies -ICT), sprzyjających rozwojowi społeczeństwa informacyjnego. Rozwój tego typu społeczeństwa wiąże się ze stosowaniem nowoczesnych technologii w różnych dziedzinach życia społecznego i gospodarczego kraju. Jeśli chodzi o funkcjonowanie administracji państwa i jej wpływ na instytucje publiczne oraz prywatne, to ważnym jego elementem jest proces informatyzacji. Komisja Europejska od końca lat 90. ubiegłego wieku w różnych projektach i strategiach uszczegóławia program rozwoju administracji elektronicznej w państwach członkowskich Unii Europejskiej. Wskazuje przy tym korzyści, które powinny towarzyszyć informatyzacji administracji publicznej państwa, szczególnie w zakresie poprawy jakości usług publicznych. Opisywane są także liczne przemiany ekonomiczne i społeczne, związane przede wszystkim ze zmniejszeniem korupcji i biurokracji, zwiększeniem stopnia transparentności organizacji publicznych oraz poprawą ich konkurencyjności. Ośrodki badawcze w krajach UE i na całym świecie podejmują próby zaprezentowania za pomocą różnych wskaźników korzyści wynikających z rozwoju e-administracji. Celem niniejszej publikacji jest zidentyfikowanie oraz ocenienie proponowanych, stosowanych współcześnie mierników stopnia rozwoju elektronicznej administracji w kontekście pomiaru korzyści wynikających z tego procesu. Korzyści związane z e-administracją mogą odnosić się bezpośrednio do zdolności konkurencyjnej państwa na płaszczyźnie międzynarodowej.

\footnotetext{
*Natalia Mańkowska - mgr, Akademia Morska w Gdyni, Wydział Przedsiębiorczości i Towaroznawstwa, Katedra Systemów Informacyjnych.
} 


\section{E-administracja w świetle współczesnych badań}

Za przyczynę rozwoju społeczeństwa informacyjnego można uznać ogólnoświatowe zmiany w procesie gromadzenia, przetwarzania i udostępniania informacji. Szczególnym rodzajem informacji jest informacja publiczna, będąca skutkiem więzi między organizacjami publicznymi a pozostałymi podmiotami funkcjonującymi w państwie. Do odbiorców tego typu informacji należą wszyscy obywatele oraz instytucje prywatne. Informacja publiczna to zbiór informacyjny, który mówi o sprawach publicznych i odnosi się do reguł funkcjonowania poszczególnych podmiotów w sferze społeczno-ekonomicznej państwa (Luterek 2010, s. 29). Przez wzgląd na różne płaszczyzny powstawania informacji publicznej wyróżnia się trzy kierunki przekazywania jej z organizacji publicznych:

1. do obywateli (ang. government to citizens - G2C);

2. do przedsiębiorstw (ang. government to business - G2B)

3. do innych jednostek administracji publicznej (ang. government to government - G2G).

Jednym z celów funkcjonowania administracji państwa powinno być umożliwienie swobodnej wymiany informacji publicznej oraz komunikacji między obywatelami, przedsiębiorstwami a jednostkami administracji publicznej (Stempnakowski 2007, s. 50). Współcześnie wymiana informacji publicznej jest ściśle powiązana $\mathrm{z}$ istnieniem odpowiedniej infrastruktury informatycznej, która powinna wspierać skuteczną komunikację między wymienionymi podmiotami. Skutkiem działań w zakresie tworzenia pożądanej infrastruktury jest koncepcja administracji elektronicznej. Administracja elektroniczna może być definiowana wąsko, jako świadczenie usług publicznych przez internet, bądź szerzej, jako użycie ICT we wszystkich procesach realizowanych przez organizacje sektora publicznego (Sakowicz 2008, s. 78). Wyróżnia się kilka definicji administracji elektronicznej w zależności od podejścia badaczy do problematyki rozwoju administracji publicznej i społeczeństwa informacyjnego w państwach. E-administracja może być określana jako wykorzystywanie technologii, szczególnie aplikacji internetowych, w celu zwiększania dostępu do informacji rządu i ulepszania procesu świadczenia usług dla obywateli, partnerów biznesowych, pracowników oraz innych agencji i podmiotów rządowych (Layne, Lee 2001). W tym ujęciu największy nacisk kładzie się na skutek wykorzystania infrastruktury informatycznej w procesie świadczenia usług publicznych, którym powinna być poprawa jakości usług w wyniku zwiększenia ich dostępności. Mówiąc szerzej, e-administracja to zastosowanie ICT $\mathrm{w}$ administracji $\mathrm{w}$ procesach świadczenia usług publicznych w celu poprawienia skuteczności menedżerskiej, promowania wartości demokratycznych oraz kreowania ram prawnych ułatwiających inicjatywy informacyjne sprzyjające intensyfikacji rozwoju społeczeństwa opartego na wiedzy (Gant 2008, s. 15). Informatyzacja administracji może zatem sprzyjać przemianom instytucji publicznych, jeśli chodzi o zwiększanie ich roli w procesie 
alokacji zasobów, a tym samym jeśli chodzi o korzyści ekonomiczne z rozwoju administracji elektronicznej. E-administracja to także, innymi słowy, proces wykorzystywania przez organizacje publiczne technologii informacyjnych i komunikacyjnych w celu przekształcenia relacji z obywatelami, przedsiębiorstwami oraz pozostałymi podmiotami (Luterek 2010, s. 34). Takie podejście do administracji elektronicznej jest najczęściej wykorzystywane w przypadku oceny społecznych skutków wdrażania strategii społeczeństwa informacyjnego na różnych płaszczyznach jego funkcjonowania w państwie.

Przemiany zachodzące w organizacjach publicznych dzięki narzędziom ICT określa się również mianem cyfrowej administracji (West 2005, s. 2), wirtualnego państwa (Fountain 2001, s. 4) oraz i-administracji (Mayer-Schonberger, Lazer 2007 , s. 2). Coraz istotniejszym kierunkiem rozwoju sfery publicznej państwa, jeśli chodzi o rozwój ICT, jest rozwój mobilnej administracji (ang. m-government) (Kushchu, Kuscu, 2003), sprowadzający się przede wszystkim do przygotowania oferty usług publicznych dostosowanych technicznie do urządzeń mobilnych.

Wykorzystanie w administracji publicznej nowoczesnych technologii informacyjnych i komunikacyjnych powinno bezpośrednio wpływać na jakość usług publicznych oraz stopień zaangażowania obywateli i przedsiębiorstw w proces podejmowania decyzji. Dlatego twierdzi się, że administracja elektroniczna powinna powodować dwa rodzaje przemian (Sakowicz 2004, s. 195):

1. polepszenie procesu świadczenia usług publicznych, którego nadrzędnym celem jest sprawne wykonywanie czynności administracyjnych dzięki efektywnemu wykorzystywaniu dostępnych zasobów;

2. poprawę stanu demokracji w wyniku zwiększenia aktywności obywateli, jeśli chodzi o proces podejmowania decyzji.

Rozwój administracji elektronicznej może wpłynąć korzystnie także na działalność organizacji publicznych, których struktura powinna (Stempnakowski 2007, s. 51):

1. cechować się otwartością i transparentnością;

2. być przyjazna, zorientowana na oczekiwania formułowane przez obywateli i przedsiębiorstwa;

3. obniżać koszty transakcyjne oraz efektywnie wspomagać proces gospodarowania zasobami sektora publicznego.

$\mathrm{Z}$ analiz dotyczących definiowania i poszukiwania korzyści płynących z informatyzacji administracji wynika, że realizacja tego procesu powinna sprzyjać przede wszystkim zwiększaniu efektywności i skuteczności decyzji rządowych. Dlatego, tworząc projekty i programy przemian struktur administracji publicznej, należy wziąć pod uwagę cztery kluczowe aspekty (Centeno i in. 2005, s. 59-60). Pierwszym jest rosnące znaczenie zarządzania wiedzą $\mathrm{w}$ procesach podejmowania decyzji oraz w procesach demokratycznych. Po drugie, dużą rolę powinny odgrywać potrzeby zgłaszane przez obywateli i przedsiębiorstw. Kolejną kwestią jest konieczność włączenia do łańcucha dostaw usług publicznych większej 
liczby pośredników. Ostatnią - wzrost rangi procesu tworzenia sieci, koordynacji i współpracy na rzecz lepszego rządzenia. Korzyści wynikające z administracji elektronicznej powinny się wiązać bezpośrednio ze zwiększaniem przejrzystości organizacji sektora publicznego, a tym samym z ograniczaniem biurokracji. Z kolei poprawa efektywności decyzji rządowych może następować w wyniku ograniczania korupcji.

\section{Narzędzia i metody pomiaru e-administracji}

Problematyka mierzenia stopnia realizacji postulatów związanych z rozwojem społeczeństwa informacyjnego w państwach jest stosunkowo nowa. Również narzędzia i metodyka badań stopnia realizacji działań związanych z wdrażaniem administracji elektronicznej nie są do końca usystematyzowane. Jednak w ciągu ostatnich dziesięciu lat pojawiło się wiele propozycji badawczych odnoszących się do tego, jak należy mierzyć administrację elektroniczną. Proponowaną przez Komisję Europejską podstawą w tym przypadku jest ocena stopnia wdrożenia usług administracji elektronicznej². Wyróżnia się pięć podstawowych możliwych do osiągnięcia stopni rozwoju e-administracji w państwie (rysunek 1).

Rysunek 1. Stopień wdrożenia usług e-administracji

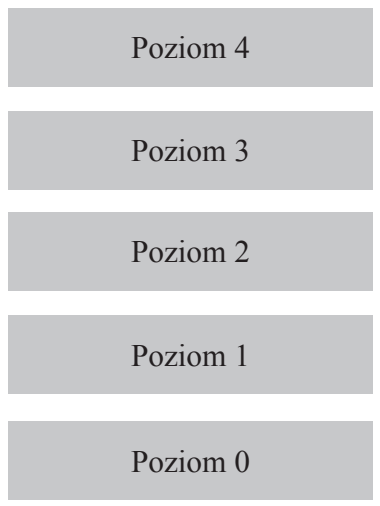

$$
\begin{aligned}
& \text { transakcja } \\
& \text { interakcja dwukierunkowa } \\
& \text { interakcja } \\
& \text { informacja } \\
& \text { usługa nie jest swiadczona elektronicznie }
\end{aligned}
$$

Źródło: D. West, Digital Government. Technology and Public Sector Performance, Princeton University Press, New Jersey 2005, s. 9.

\footnotetext{
${ }^{2}$ Komisja Unii Europejskiej w 2005 r. zarekomendowała 20 podstawowych usług publicznych, które powinny być świadczone drogą elektroniczną: dla przedsiębiorstw - ubezpieczenia społeczne (ZUS), podatek od osób prawnych, podatek VAT, rejestracja działalności gospodarczej, wysyłanie danych statystycznych, deklaracje celne, zezwolenia i certyfikaty (np. środowiskowe), zamówienia publiczne; dla obywateli - podatek od osób fizycznych, pośrednictwo pracy, usługi Urzędów Pracy, świadczenia społeczne, dokumenty tożsamości, rejestracja pojazdów, pozwolenie na budowę, policja - obsługa zgłoszeń, katalog bibliotek publicznych, certyfikaty (akty urodzeń, zgonu lub zawarcia małżeństwa), rejestracja kandydatów na wyższe uczelnie, ewidencja meldunkowa, usługi związane ze zdrowiem.
} 
Poziom zero odnosi się do sytuacji, w której dana usługa nie jest dostępna elektronicznie. Poziom pierwszy to dostępny w internecie opis o tym, jak należy załatwić daną usługę publiczną. Na tym poziomie wdrożenia nie ma możliwości nawiązania dwukierunkowej komunikacji z jednostką administracji publicznej. $\mathrm{Na}$ poziomie drugim rozwiązania technologiczne pozwalają na ułatwienia, jeśli chodzi o realizację usługi publicznej, polegające np. na dostępności formularza. Na poziomie trzecim możliwe jest odesłanie wypełnionego formularza do odpowiedniej organizacji publicznej (uproszczona komunikacja dwukierunkowa). Na poziomie czwartym usługa publiczna jest dostępna w całości na platformie elektronicznej, online codziennie przez całą dobę (24/7). Z prowadzonych dotąd badań wynika, że w wielu krajach brakuje jeszcze odpowiedniej infrastruktury, która pozwoliłaby na kompleksową realizację czynności administracyjnych z wykorzystaniem ICT. Ocenia się, że w wielu przypadkach nie ma spójnej inicjatywy, jeśli chodzi o wprowadzanie elektronicznych usług publicznych (Brown i in. 2006, s. 40).

Oprócz stopnia wdrożenia usług e-administracji istotnymi narzędziami pomiaru informatyzacji administracji publicznej są mierniki, które mają za zadanie pokazać wpływ ICT na różne elementy systemu zarządzania organizacją publiczną oraz na efektywność, skuteczność i sprawność działania tych podmiotów. Od kilku lat różne ośrodki badawcze podejmują próby skonstruowania wskaźnika stopnia rozwoju e-administracji. Biorą przy tym pod uwagę wybrany koszyk korzyści, które przynosi informatyzacja samej organizacji i/lub odbiorcom jej usług. Wybrane wskaźniki opisano w tabeli 1.

Tabela 1. Wybrane wskaźniki pomiaru e-administracji

\begin{tabular}{|c|c|c|c|c|}
\hline Nazwa wskaźnika & Akronim & Rok & $\begin{array}{l}\text { Ośrodek badaw- } \\
\text { czy / organizacja }\end{array}$ & Opis wskaźnika \\
\hline $\begin{array}{l}\text { Zrównoważony } \\
\text { indeks rozwoju } \\
\text { e-administracji } \\
\text { (ang. Balanced } \\
\text { E-Government } \\
\text { Index) }\end{array}$ & BEGIX & $\begin{array}{l}2001- \\
2002\end{array}$ & $\begin{array}{l}\text { Bertelsmann } \\
\text { Foundation and } \\
\text { Booz, Allen and } \\
\text { Hamilton }\end{array}$ & $\begin{array}{l}\text { Karta wyników pozwalająca na } \\
\text { sprawdzenie stopnia realizacji } \\
\text { różnych celów w ramach strategii. } \\
\text { Ocena e-administracji i e-demo- } \\
\text { kracji tworzona jest za pomoca } \\
\text { macierzy zawierającej składnik } \\
\text { dynamiczny i statyczny z pięciu } \\
\text { dziedzin: korzyści, efektywności, } \\
\text { uczestnictwa, przejrzystości, } \\
\text { zarządzania zmianą }\end{array}$ \\
\hline $\begin{array}{l}\text { Metodologia } \\
\text { wyceny wartości } \\
\text { (ang. Value } \\
\text { Measuring } \\
\text { Methodology) }\end{array}$ & VMM & $\begin{array}{l}2001- \\
2003\end{array}$ & $\begin{array}{l}\text { US Social Se- } \\
\text { curity Admin- } \\
\text { istration oraz } \\
\text { General Service } \\
\text { Administration }\end{array}$ & $\begin{array}{l}\text { Narzędzie VMM służy do opra- } \\
\text { cowywania ram wartości, w tym } \\
\text { kosztów, ryzyka, zysków mate- } \\
\text { rialnych oraz niematerialnych } \\
\text { z inwestycji e-administracji }\end{array}$ \\
\hline $\begin{array}{l}\text { Model referen- } \\
\text { cyjny wydajno- } \\
\text { ści (ang. Perfor- } \\
\text { mance Reference } \\
\text { Model) }\end{array}$ & PRM & 2003 & $\begin{array}{l}\text { US Federal En- } \\
\text { terprise Archi- } \\
\text { tecture Program } \\
\text { Management } \\
\text { Office }\end{array}$ & $\begin{array}{l}\text { Narzędzie oceny przetwarzanych } \\
\text { informacji publicznych w kontek- } \\
\text { ście ich wydajności. Na wskaźnik } \\
\text { składają się cztery obszary pomia- } \\
\text { rowe: realizacja misji, procesy, } \\
\text { wyniki obywateli i przedsię- } \\
\text { biorstw oraz technologia }\end{array}$ \\
\hline
\end{tabular}




\begin{tabular}{|c|c|c|c|c|}
\hline $\begin{array}{l}\text { Wartość publicz- } \\
\text { na z IT (ang. } \\
\text { Public Value } \\
\text { of IT) }\end{array}$ & PVIT & $\begin{array}{l}2003- \\
2004\end{array}$ & $\begin{array}{l}\text { Andrea Di } \\
\text { Maio, Research } \\
\text { Vice President } \\
\text { at Gartner }\end{array}$ & $\begin{array}{l}\text { Miernik prezentujący wpływ wy- } \\
\text { korzystania ICT w administracji na } \\
\text { jakość obsługi, efektywność opera- } \\
\text { cyjną oraz polityczną stopę zwrotu }\end{array}$ \\
\hline $\begin{array}{l}\text { Popyt i meto- } \\
\text { dologia oceny } \\
\text { wartości (and. } \\
\text { Demand and } \\
\text { Value Assessment } \\
\text { Methodology) }\end{array}$ & $\begin{array}{l}\text { DAM } \\
\text { \& VAM }\end{array}$ & 2004 & $\begin{array}{l}\text { Australian Gov- } \\
\text { ernment Infor- } \\
\text { mation Manage- } \\
\text { ment Office }\end{array}$ & $\begin{array}{l}\text { Ocena usług rządowych w oparciu } \\
\text { o dwa kryteria: popyt i wartość. } \\
\text { Popyt jako obraz potrzeb użyt- } \\
\text { kowników końcowych usług } \\
\text { publicznych. Wartość uwzględnia } \\
\text { konsekwencje, które przynosi } \\
\text { dana usługa w zakresie tworzenia } \\
\text { ładu społecznego }\end{array}$ \\
\hline $\begin{array}{l}\text { Wyniki pomiaru } \\
\text { inicjatyw wdra- } \\
\text { żania usług pu- } \\
\text { blicznych on-line } \\
\text { (ang. Performan- } \\
\text { ce Measurement } \\
\text { for the Govern- } \\
\text { ment On-Line } \\
\text { Initiative) }\end{array}$ & PMAF & 2004 & $\begin{array}{l}\text { Treasury Board } \\
\text { of Canada Sec- } \\
\text { retariat }\end{array}$ & $\begin{array}{l}\text { Narzędzie oceniające wpływ } \\
\text { e-administracji za pomocą ana- } \\
\text { lizy zmian na czterech płasz-- } \\
\text { czyznach: stopnia dostępności } \\
\text { e-usług oraz rzetelnej informacji } \\
\text { publicznej, badania jakości usług } \\
\text { oraz stopnia zadowolenia z ofer- } \\
\text { ty, badania poziomu zaufania do } \\
\text { usług świadczonych elektronicz- } \\
\text { nie, analizy pozytywnych skut- } \\
\text { ków gospodarczych }\end{array}$ \\
\hline $\begin{array}{l}\text { Wartość } \\
\text { publiczna } \\
\mathrm{z} \text { e-administracji } \\
\text { (ang. Public } \\
\text { Value of } \\
\text { E-Government) }\end{array}$ & PVEG & 2004 & $\begin{array}{l}\text { Komisja } \\
\text { Europejska }\end{array}$ & $\begin{array}{l}\text { Zgodnie z koncepcją wartość } \\
\text { publiczna e-administracji jest } \\
\text { definiowana jako wartość wspól- } \\
\text { na dla wszystkich obywateli, } \\
\text { przedsiębiorstw, organizacji oraz } \\
\text { grup nieformalnych. Stanowi ona } \\
\text { wynik decyzji w zakresie podziału } \\
\text { zasobów podejmowanych przez } \\
\text { wszystkie podmioty prowadzące } \\
\text { działalność w społeczeństwie } \\
\text { rozpatrywanym jako całość }\end{array}$ \\
\hline $\begin{array}{l}\text { Ramy pomiaru } \\
\text { e-rządzenia (ang. } \\
\text { E-Governence } \\
\text { Assessment } \\
\text { Framework) }\end{array}$ & $\begin{array}{l}\text { EAF } \\
\text { Version } \\
2.0\end{array}$ & 2004 & $\begin{array}{l}\text { Department of } \\
\text { IT, India oraz } \\
\text { National Insti- } \\
\text { tute for Smart } \\
\text { Governance }\end{array}$ & $\begin{array}{l}\text { Wskaźnik oceny e-administracji, } \\
\text { którego ramy pomiaru odnosza } \\
\text { się do m.in. stopnia, w jakim dany } \\
\text { projekt e-administracji ma cechy } \\
\text { dobrego projektu, badania cyklu } \\
\text { życia projektów e-administracji, } \\
\text { przygotowania materiału do pro- } \\
\text { gramów szkoleniowych e-admini- } \\
\text { stracji, analizy poziomu zaufania } \\
\text { do projektów e-administracji }\end{array}$ \\
\hline $\begin{array}{l}\text { Ramy wartości } \\
\text { publicznej (ang. } \\
\text { Public Value } \\
\text { Framework) }\end{array}$ & PVF & 2006 & $\begin{array}{l}\text { Center } \\
\text { for Technology } \\
\text { in Government, } \\
\text { University } \\
\text { at Albany }\end{array}$ & $\begin{array}{l}\text { Wskaźnik ukazujący wpływ } \\
\text { e-administracji na poszczególne } \\
\text { elementy systemu zarządzania } \\
\text { organizacjami publicznymi } \\
\text { i spadek kosztów }\end{array}$ \\
\hline
\end{tabular}

Źródło: opracowanie własne na podstawie N. Prakash, M.P. Jaiswal, U. Gulla, Measurement of Public Value of Enterprise Applications in Government and Public Sector, Methodology, Vol. 2005, 03, s. $169-170$.

Prawie wszystkie zaprezentowane w tabeli metody pomiaru e-administracji odwołują się do sposobu, w jaki informatyzowana organizacja publiczna uczestni- 
czy w procesie tworzenia dodatkowej wartości dla odbiorców jej usług. Zróżnicowany jest zakres badanych korzyści i sposób określania ich wartości. Wynika on zwykle z szeroko rozumianych decyzji o alokacji zasobów podejmowanych przez wszystkie podmioty korzystające z e-administracji. Z tego względu ocenia się, że pożądanym kierunkiem zmian jest dążenie do optymalizacji, które będzie polegało na maksymalizacji korzyści osiąganych przez wszystkich interesariuszy w społeczeństwie za pomocą administracji (Botterman, Millard 2009, s. 101). Wdrażanie elektronicznej administracji powinno wpływać na zwiększanie oszczędności i efektywności działań podejmowanych przez organizacje publiczne, a ponadto przynosić korzyści państwu w sferze społeczno-ekonomicznej.

\section{Pomiar e-administracji a konkurencyjność międzynarodowa}

Konkurencyjność międzynarodowa to zbiór czynników, polityk oraz instytucji określających poziom produktywności kraju, powodujących, że gospodarka narodowa osiąga zrównoważony poziom dobrobytu (Schwab 2013, s. 4). Twórcy definicji konkurencyjności międzynarodowej w literaturze przedmiotu współcześnie często odwołują się do pojęcia pozycji konkurencyjnej oraz zdolności konkurencyjnej. Z tego względu różnicowane są także mierniki konkurencyjności międzynarodowej. Można je podzielić na dwie grupy (Bossak 2008, s. 576). Pierwsza to grupa miar pozycji konkurencyjnej kraju, odwołująca się do danych ex post, oceniająca potencjał państwa na arenie międzynarodowej z wykorzystaniem metod statystyczno-ilościowych uzupełnionych o wskaźniki kompozytowe oparte na badaniach jakościowych (do tej kategorii badań należą m.in. coroczne raporty Światowego Forum Ekonomicznego oraz Instytutu Rozwoju Zarządzania w Lozannie). Do drugiej grupy miar należy ujęcie konkurencyjności na podstawie danych ex ante, mające charakter przyczynowo-skutkowy, ukazujące niepewność, prawdopodobieństwo oraz interaktywność zachowań podmiotu, które mogą świadczyć o jego zdolności konkurencyjnej. Zdolność konkurencyjna odnosi się zwykle do efektywnych działań gospodarki w niepewnej przyszłości. Stąd pojęcie zdolności konkurencyjnej zawsze wiąże się z oceną (Onsel i in. 2008, s. 222): postępu technologicznego, jakości instytucji publicznych w państwie, infrastruktury, jakości zarządzania w organizacjach publicznych i prywatnych oraz szeroko rozumianej stabilności gospodarki. Rozwój administracji elektronicznej może opierać się zarówno na procesach zwiększania postępu technologicznego, jak i na poprawie infrastruktury, która będzie sprzyjała poprawie jakości instytucji publicznych i decyzji o alokacji zasobów realizowanych przez organizacje publiczne.

Jeśli chodzi o narzędzia pomiaru administracji elektronicznej i powiązanie ich metodyki badawczej z poziomem konkurencyjności międzynarodowej, to szczególne znaczenie ma wskaźnik proponowany przez Komisję Europejską - 
wartość publiczna z e-administracji. Idea tworzenia wartości publicznej z e-administracji zakłada ponoszenie następujących konsekwencji (rysunek 2).

Rysunek 2. Wartość publiczna z e-administracji - kontekst operacyjny i wynikowy

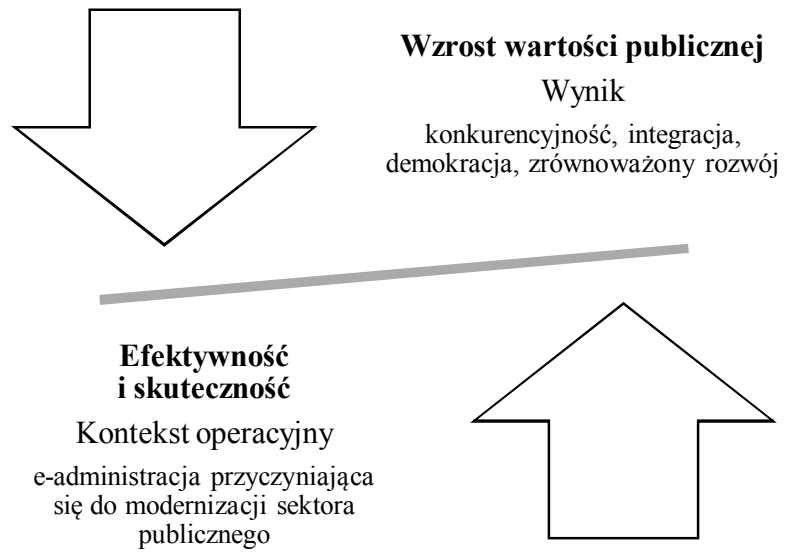

Źródło: J. Millard, J. Shahin, R. Warren, C. Leitner, Towards the eGovernment vision for EU in 2010: research policy challenges, Instytut Perspektywicznych Badań Technologicznych, Komisja Europejska Dyrekcja Generalna, Wspólne Centrum Badawcze, Sewilla 2006, s. 17.

Wdrażanie e-administracji powinno być oceniane w kontekście wynikowym i operacyjnym. Pożądane jest uzyskanie wyników sprzyjających rozwojowi sfery społeczno-ekonomicznej. Zgodnie z koncepcją PVEG wzrost wartości publicznej może być szacowany na podstawie rezultatów w zakresie: gospodarczym (poprawa konkurencyjności oraz wzrost innowacyjności państwa), społecznym (wzmocnienie integracji i roli decyzji obywatelskich, poprawa jakości życia obywateli oraz stanu środowiska) oraz politycznym (wzmocnienie demokracji przez wykorzystanie ICT).

\section{Zakończenie}

Rozwój administracji elektronicznej jest jednym z podstawowych programów realizowanych $\mathrm{w}$ ramach strategii społeczeństwa informacyjnego. Wraz z wdrażaniem nowoczesnych technologii informacyjnych i komunikacyjnych w administracji publicznej zaczęto podejmować próby zmierzenia korzyści wynikających $\mathrm{z}$ tego procesu. Współcześnie problematyka badawcza dotycząca pomiaru e-administracji w kontekście zwiększania poziomu konkurencyjności międzynarodowej w dużej mierze odnosi się do różnych koncepcji badawczych wyznaczania stopnia rozwoju administracji elektronicznej. W ciągu ostatnich lat stworzono wiele koncepcji mających za zadanie skwantyfikować korzyści i oszacować 
wartość informatyzacji administracji. Najczęściej wspominaną i najszerzej opisaną teoretycznie jest idea wartości publicznej z e-administracji, opracowana przez Komisję Europejską. Zgodnie z założeniami tej koncepcji rozwój administracji elektronicznej powinien sprzyjać powstawaniu szeroko rozumianej wartości publicznej dla wszystkich podmiotów uczestniczących w podziale zasobów w państwie. Można również skonstatować, że proces powstawania wartości publicznej z e-administracji ma swoje źródło w sferach podobnych do tych, które pojawiają się w przypadku procesów sprzyjających poprawie konkurencyjności państwa. Nie ma jednak wielu badań wykorzystujących bogate źródła danych, ukazujących problematykę rozwoju administracji elektronicznej w perspektywie globalnej. Próbą połączenia tego typu zmiennych jest stworzenie indeksu dojrzałości e-administracji (Srivastava $i$ in. 2008, s. 86-87). Wyniki badań prowadzonych dotychczas w omawianym zakresie wskazują, że e-administracja stanowiąca składową otoczenia instytucjonalnego przedsiębiorstw jest istotnie związana z poziomem ich konkurencyjności, a tym samym ma swoje odzwierciedlenie w konkurencyjności międzynarodowej.

\section{Bibliografia}

Bossak J. (2008), Konkurencyjność gospodarki Polski a proces integracji europejskiej i rozwoju gospodarki opartej na wiedzy [w:] Michalski T., Piech K. (red.), Konkurencyjność Polski w procesie poglębiania integracji europejskiej i budowy gospodarki opartej na wiedzy, SGH w Warszawie - Oficyna Wydawnicza, Warszawa.

Botterman M., Millard J. (2009), Value for citizens: A vision of public governance in 2020. Raport dla Komisji Europejskiej, Dyrekcja Generalna ds. Społeczeństwa Informacyjnego i Mediów, Bruksela.

Brown R., Silbergh D., Sartorius W., Combe C. (2006), Administrative Capacity Review of Poland, Background Paper, Washington.

Centeno C., van Bavel R., Burgelman J.C. (2005), A Prospective View of e-Government in the European Union, The Electronic Journal of e-Government, Vol. 3, Issue 2.

Europejskie Regionalne Stowarzyszenie Społeczeństwa Informacyjnego (2007), Podręcznik dobrych praktyk regionalnych-e-administracja, Stowarzyszenie „Miasta w Internecie”, Tarnów.

Fountain J. (2001), Building the Virtual State. Information Technology and Institutional Change, The Brookings Institutions, Washington.

Gant J.P. (2008), Electronic Government for Developing Countries, ITU Telecommunication Development Sector's ICT Applications and Cybersecurity Division, Geneva.

Hart-Teeter Research Companies (2001), E-Government. The Next American Revolution, The Council For Excellence in Government, Washington. 
Kushchu I., Kuscu M. (2003), From e-Government to m-Government: Facing the Inevitable, The 3rd European Conference on e-Government.

Layne K., Lee J. (2001), Developing fully functional E-government: A four stage model, Elsevier, Government Information Quarterly, Vol. 18, Issue 2, Summer.

Luterek M. (2010), E-government, Wyd. Akademickie i Profesjonalne, Warszawa.

Mayer-Schonberger V., Lazer D. (2007), Governance and Information Technology: from Electronic Government to Information Government, Massachussets Institute of Technology, Massachussets.

Millard J., Shahin J., Warren R., Leitner C. (2006), Towards the eGovernment vision for EU in 2010: research policy challenges, Instytut Perspektywicznych Badań Technologicznych, Komisja Europejska, Dyrekcja Generalna, Wspólne Centrum Badawcze, Sewilla.

Onsel S., Ulengin F., Ulusoy G., Aktas E., Kabak O., Topcu Y. (2008), A new prospective on the competitiveness of nations, Socio-Economic Planing Sciences 42, Elsevier.

Prakash N., Jaiswal M.P., Gulla U. (2005), Measurement of Public Value of Enterprise Applications in Government and Public Sector, Methodology, Vol. 03.

Sakowicz M. (2004), The use of ICT in Polish local authorities: Improving the quality of local democracy and public services [w:] Loffler E., Vintar M. (red.), Improving the quality of East and West European public services, Ashgate, Bratislava.

Sakowicz M. (2008), Zastosowanie nowych technologii informacyjno-komunikacyjnych $w$ rzadzeniu $i$ zarzadzaniu administracja publiczna [w:] Osiński J. (red.), Administracja publiczna na progu XXI wieku. Wyzwania i oczekiwania, SGH w Warszawie - Oficyna Wyd., Warszawa.

Schwab K. (2013), Global Competitiveness Report 2012-2013, World Economic Forum.

Srivastava C., Shirish C., Thompson S.H. (2008), The Relationship between E-Government and National Competitiveness: The Moderating Influence of Environmental Factors, Communications of the Association for Information Systems, Vol. 23, Article 5.

Stempnakowski Z. (2007), Administracja elektroniczna [w:] Szewczyk A. (red.), Społeczeństwo informacyjne - problemy rozwoju, Difin, Warszawa.

West D. (2005), Digital Government. Technology and Public Sector Performance, Princeton University Press, New Jersey.

\section{Streszczenie}

Przedmiotem rozważań zawartych w publikacji jest problematyka zależności między procesem wdrażania administracji elektronicznej a zdolnością konkurencyjną kraju. Współcześnie ocenia się, że kluczowym celem informatyzacji administracji 
publicznej, zarówno na szczeblu centralnym, jak i lokalnym, jest produktywne i efektywne przygotowanie oraz wdrożenie elektronicznych usług publicznych dla obywateli i przedsiębiorstw. Wizja e-administracji przedstawiona przez Komisję Europejską oraz stopniowo realizowana przez państwa członkowskie UE ukazuje, że proces rozwoju e-administracji powinien służyć jako narzędzie wspomagające procesy rządzenia. Projekty związane z informatyzacją mogą wpływać m.in. na poprawę systemu edukacji i służby zdrowia, tworzenie nowych miejsc pracy, zmianę sposobów zarządzania zasobami, zmniejszenie kosztów transakcyjnych i ogólne przemiany instytucjonalne. Stosowane obecnie narzędzia pomiaru korzyści wynikających z wdrażania e-usług publicznych i ogólnie rozwoju e-administracji nie zawsze ukazują je wprost. Celem publikacji jest zidentyfikowanie i ocenienie stosowanych obecnie mierników stopnia rozwoju administracji elektronicznej w kontekście pomiaru korzyści wynikających z tego procesu, mających znaczenie dla poprawy konkurencyjności państwa na arenie międzynarodowej.

Słowa kluczowe: e-administracja, konkurencyjność międzynarodowa, wartość publiczna z e-administracji

\section{Summary}

\section{Methods of measurement e-government in the context of international competitiveness}

The subject under discussion is the problem of publications on the relationship between the e-government implementation process and the ability to compete. Today, it is estimated that the key objective of the informatisation of public administration at both central and local levels, is the preparation and implementation of electronic public services for citizens and businesses productively and efficiently. The e-government vision presented by the European Commission, and gradually implemented through EU Member States shows, that the process of developing e-government should serve as a tool to support the processes of governance. Projects related to the informatisation may influence the improvement of the education system and health services, create jobs, change how resources are managed, reduce transaction costs and the overall transformation of institutional nature. The currently used measuring tools of benefits from the implementation of public e-services and general development of e-government do not always show directly whether they are generated. The purpose of the publication is to identify and evaluate currently used indicators of electronic administration development in the context of measuring the benefits of this process, which are significant for improving the country's competitiveness in the international arena.

Keywords: e-government, national competitiveness, public value of e-government JEL: D73, H11, O33 